University of Wollongong

Research Online

Faculty of Engineering - Papers (Archive)

Faculty of Engineering and Information

Sciences

September 2005

\title{
Measurement of pore water pressure of clay-infilled rock joints during triaxial shearing
}

Buddhima Indraratna

University of Wollongong, indra@uow.edu.au

J. Mylvaganam

University of Wollongong

Follow this and additional works at: https://ro.uow.edu.au/engpapers

Part of the Engineering Commons

https://ro.uow.edu.au/engpapers/392

\section{Recommended Citation}

Indraratna, Buddhima and Mylvaganam, J.: Measurement of pore water pressure of clay-infilled rock joints during triaxial shearing 2005.

https://ro.uow.edu.au/engpapers/392

Research Online is the open access institutional repository for the University of Wollongong. For further information contact the UOW Library: research-pubs@uow.edu.au 


\title{
TECHNICAL NOTE
}

\section{Measurement of pore water pressure of clay-infilled rock joints during triaxial shearing}

\author{
B. INDRARATNA* and M. JAYANATHAN*
}

KEYWORDS: clays; laboratory tests; pore pressure; rocks/rock mechanics; shear strength

\section{INTRODUCTION}

Joints existing within a rock mass are normally filled with fine materials such as clay and silt, which decrease its ultimate strength and make it easier to deform. The shear behaviour of infilled rock joints is controlled by several parameters, such as infill thickness, joint roughness and drainage conditions (Ladanyi \& Archambault, 1977; Lama, 1978; de Toledo \& de Freitas, 1993; Indraratna et al., 2005). If the infill material is saturated and drainage is impeded, pore water pressure within the infilled joint will build up and change during shear displacement. The importance of pore water pressure in the hydromechanical stability of jointed rock mass has been recognised for several decades (Lane, 1970). Several catastrophic failures of natural rock slopes have occurred as a result of pore water pressure build-up in jointed rock (e.g. Kangaroo Valley rockslide, NSW, Australia; Indraratna \& Ranjith, 2001). Limited experimental studies on the effect of pore water pressure in rock specimens (porous or fractured) have been reported by Lane (1970), Goodman \& Ohnishi (1973) and Poirier et al. (1994). Even fewer studies have been dedicated to jointed rock behaviour under undrained conditions including pore water pressure behaviour, but without any infill (e.g. Archambault et al., 1998, 1999). In this paper, the authors describe some limited but interesting test results on the behaviour of clay-infilled joints sheared under triaxial, undrained conditions.

\section{SIMULATED INFILLED ROCK JOINT AND SAMPLE PREPARATION}

The infill material was collected from a rockslide site at Kangaroo Valley, NSW (170 km south of Sydney). It can be described as silty clay with a natural water content of about $22 \%$, and a dry unit weight of $18.2 \mathrm{kN} / \mathrm{m}^{3}$. It is of low to moderate plasticity with a liquid limit (LL) of $36-38 \%$ and a plastic limit (PL) of $21-22 \%$, giving a plasticity index (PI) of $15-16 \%$. The natural infill as brought from the site was clumpy as well as containing some coarse gravel. Therefore the infill had to be pulverised before using it for the smaller laboratory joints (i.e. scale effect). The maximum grain size of the laboratory infill was less than $425 \mu \mathrm{m}$, as determined by sieve analysis. The infill was then mixed with water (approximately $30 \%$ by weight) using a mechanical mixer to maintain homogeneity. A sufficient quantity of the mixed sample was stored in airtight polythene bags for use during the entire experimental phase.

Because of the need for repetitive tests, model rock joints with a regular sawtooth surface profile (asperity height $a=$ $2 \mathrm{~mm}$, and initial asperity angle $\alpha=18^{\circ}$ ) were cast. The joint profile and the mould (Fig. 1) were machined from acetal

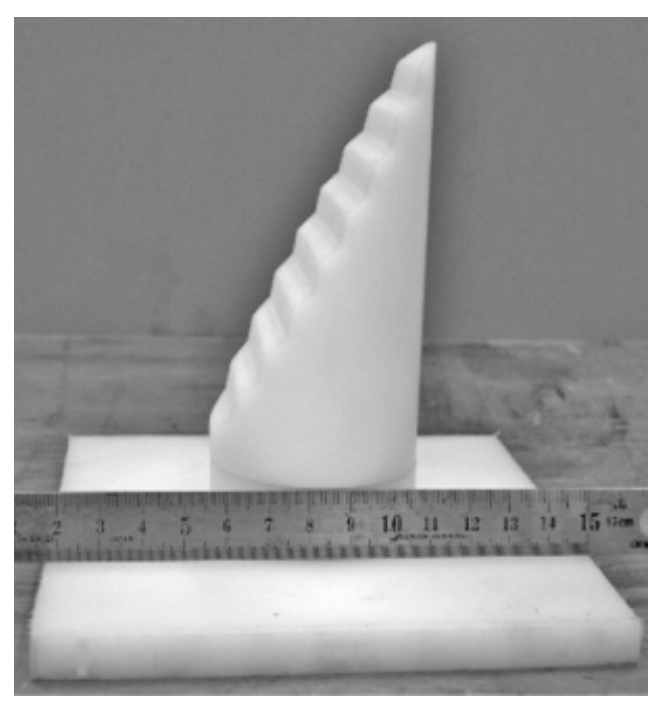

(a)

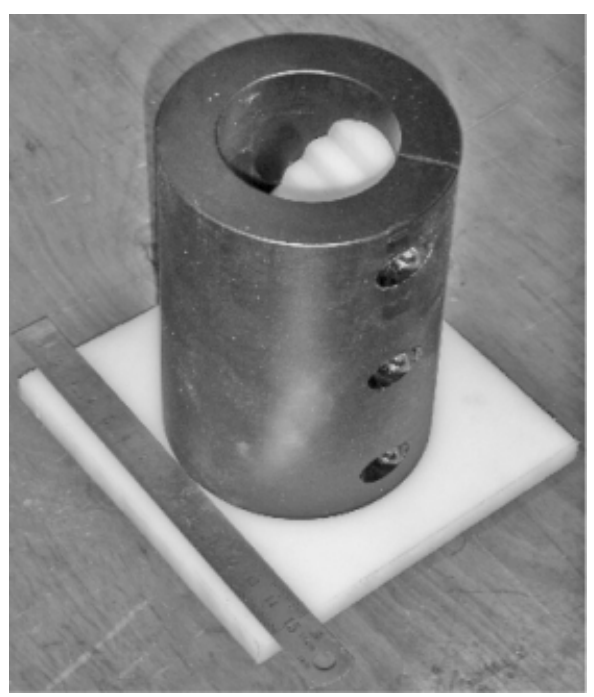

(b)

Fig. 1. (a) Simulated joint surface profile and (b) mould for casting

Manuscript received 11 January 2005; revised manuscript accepted 17 October 2005.

Discussion on this paper closes 1 June 2006, for further details see p. ii.

* Faculty of Engineering, University of Wollongong, Australia. 
plastic. Jointed specimens, $54 \mathrm{~mm}$ in diameter with a dip angle of $\beta=60^{\circ}$, were cast with gypsum plaster blended with water in a 5:3 ratio by weight. The cured plaster showed a consistent unconfined compressive strength $\left(\sigma_{\mathrm{c}}\right)$ in the range $11-13 \mathrm{MPa}$ and a Young's modulus $(E)$ of $1 \cdot 9-2 \cdot 3 \mathrm{GPa}$. The mechanical properties of this low-porosity model material have been reported by Indraratna (1990) and Indraratna et al. (1999). A 2 mm diameter piezometer hole (Fig. 2) was drilled into the centre of the model rock specimen to saturate the infill by back-pressure and to measure pore water pressure during shearing. A $5 \mathrm{~mm}$ diameter porous stone and filter paper were placed where the piezometer hole intercepted the joint surface, as shown in Fig. 3. The plaster specimens were immersed in water for at least $72 \mathrm{~h}$, and subsequently an organic waterproof sealant was applied over the joint surfaces before the mixed infill was placed between the 'mating' joint surfaces. Both halves were assembled and aligned using a scaled 'V' block (Fig. 2). For a specified infill thickness $(t)$, the mated sample was adjusted and trimmed to form a cylindrical infilled rock joint. After assembly, the specimens were wrapped in a thin latex (impervious) membrane. According to ISRM standards, a height to diameter ratio of $2 \cdot 0$
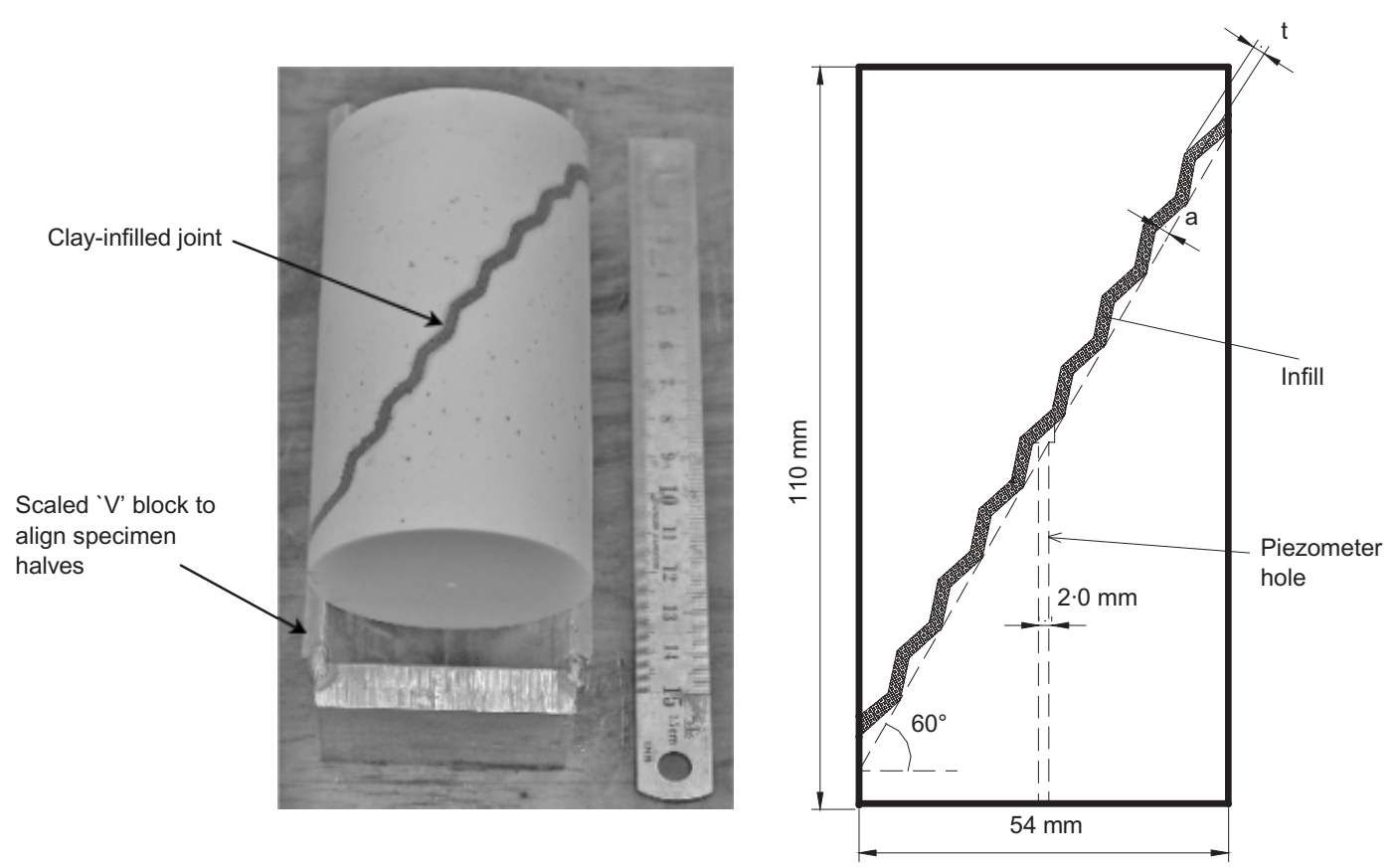

Fig. 2. Clay-infilled model rock joint

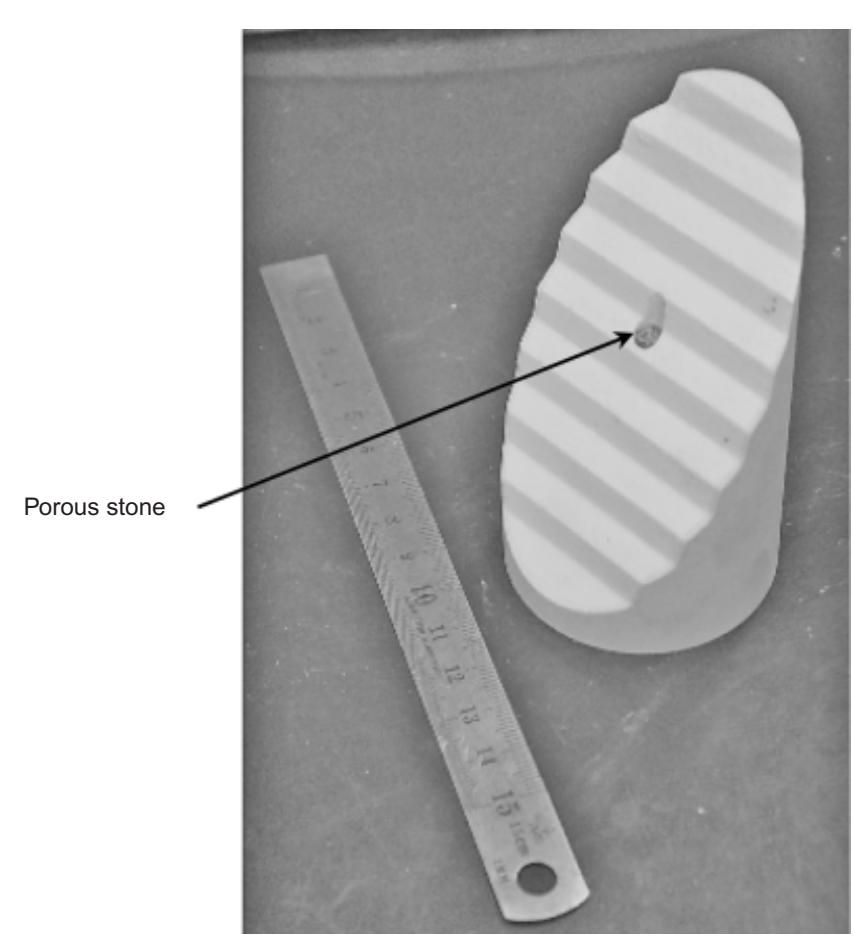

Fig. 3. Bottom half of joint specimen with piezometer hole for pore pressure measurement

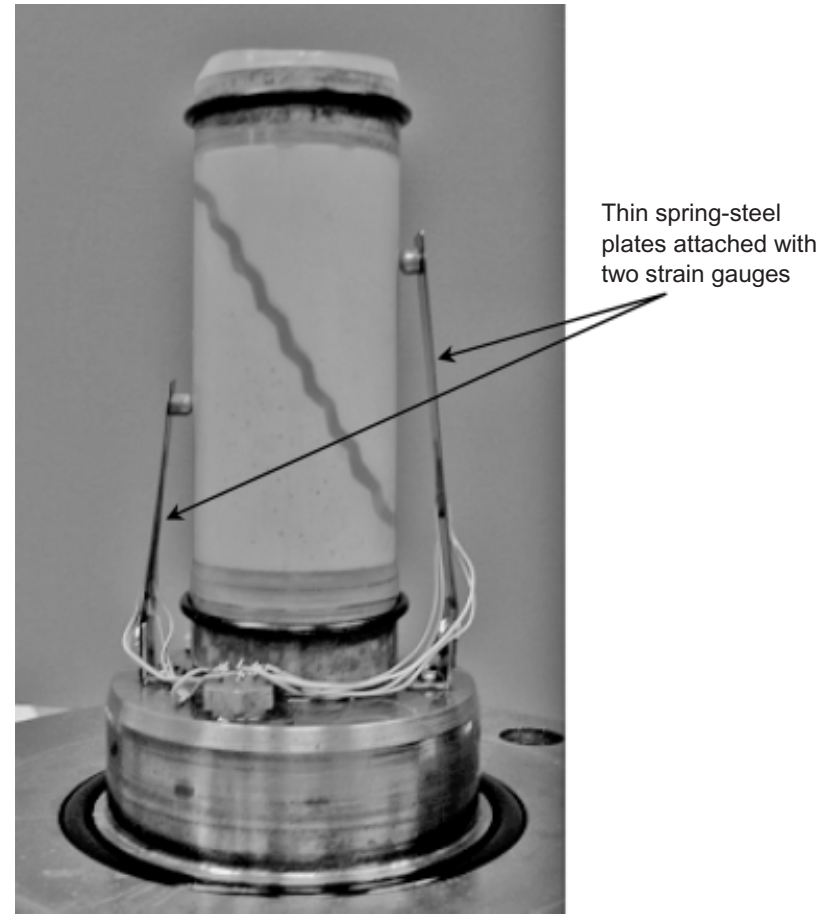

Fig. 4. An arrangement for measuring horizontal displacement during shearing 
and an end roughness not exceeding $0.01 \mathrm{~mm}$ were established. During testing, the sealant applied on the joint surfaces and the impervious latex membrane tightly wrapping the joint specimen ensured an undrained condition of the clay infill. For joints with thinner infill, the sealant may be damaged during asperity shearing. However, as the permeability of the model rock is much smaller than that of the infill $\left(k_{\text {infill }} / k_{\text {rock }}>1000\right)$, it may be assumed that undrained conditions would still prevail.

\section{EXPERIMENTAL PROCEDURE}

\section{Test apparatus}

The high-pressure two-phase triaxial apparatus at the University of Wollongong (Indraratna \& Haque, 1999) was modified for this study. A variable constant-strain mechanical driving system was installed to apply a constant axial strain rate to the infilled joint under a given confining pressure. The loading capacity of the driving system was $150 \mathrm{kN}$ and the travel length $120 \mathrm{~mm}$. A load cell and a linear variable displacement transducer (LVDT) were used to measure the axial load and vertical displacement respectively. A system

$$
\sigma_{3}^{\prime}=200 \mathrm{kPa}
$$

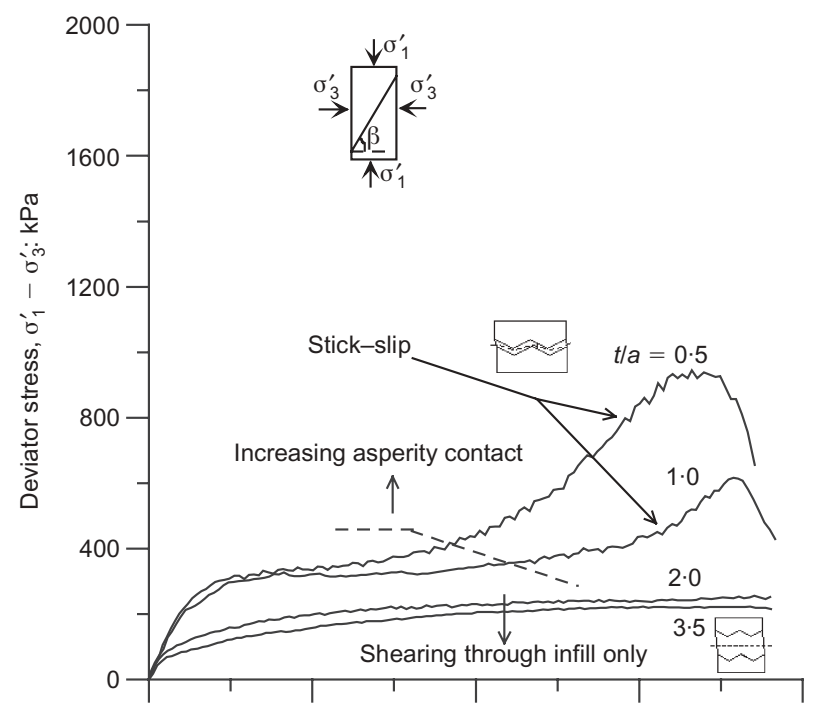

(a)

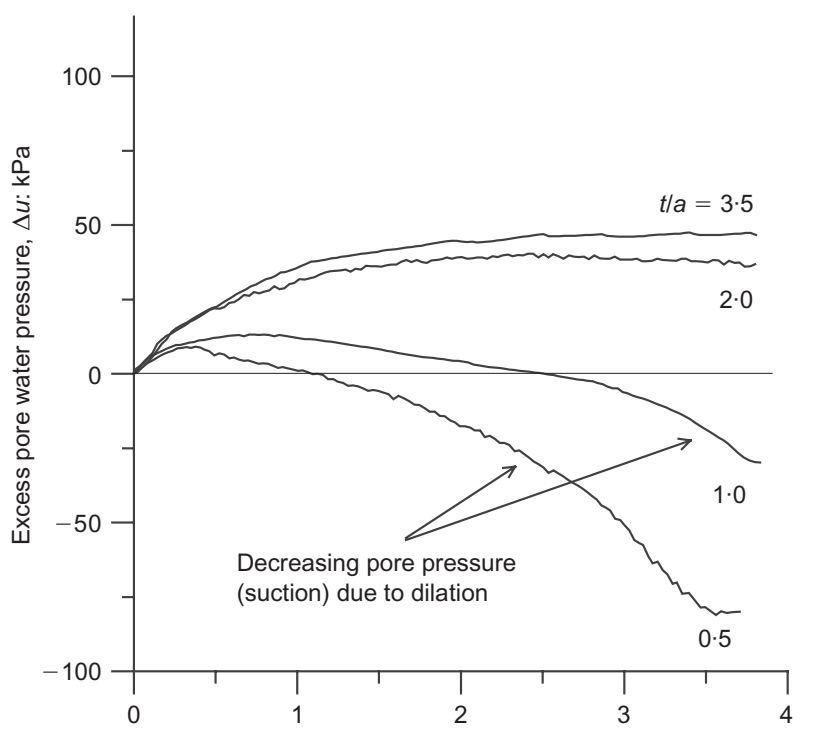

(c) of two thin spring-steel cantilever arms was mounted on the base of the triaxial cell (Fig. 4) for measuring horizontal displacement. Two strain gauges were attached to each arm and connected to a Wheatstone bridge. The dilation and compression components perpendicular to the joint surface were determined from the horizontal and axial displacement, based on the following equation:

Dilation, $\Delta v=\Delta x \sin \beta-\Delta z \cos \beta$

where $\Delta x$ is the horizontal displacement and $\Delta z$ is the axial displacement.

Pressure transducers were connected to the fluid lines to measure confining pressure and pore pressure, and then all the devices were connected to a computer-based data logger. Silicon oil was used as confining fluid because it prevents corrosion of the steel cell and does not react with the latex membrane.

\section{Consolidated undrained triaxial test}

The clay-infilled jointed specimen previously wrapped in latex was assembled inside the modified triaxial cell. Con-

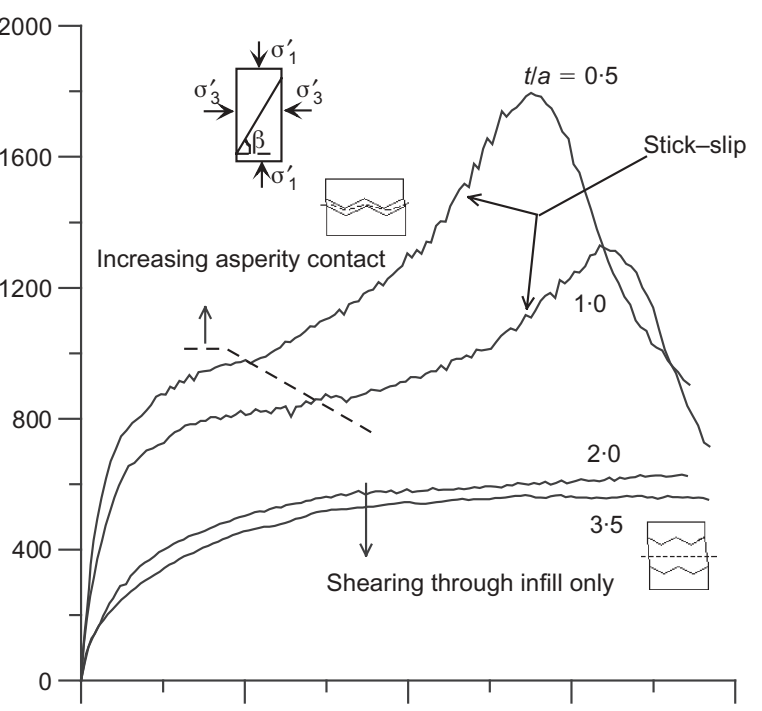

(b)

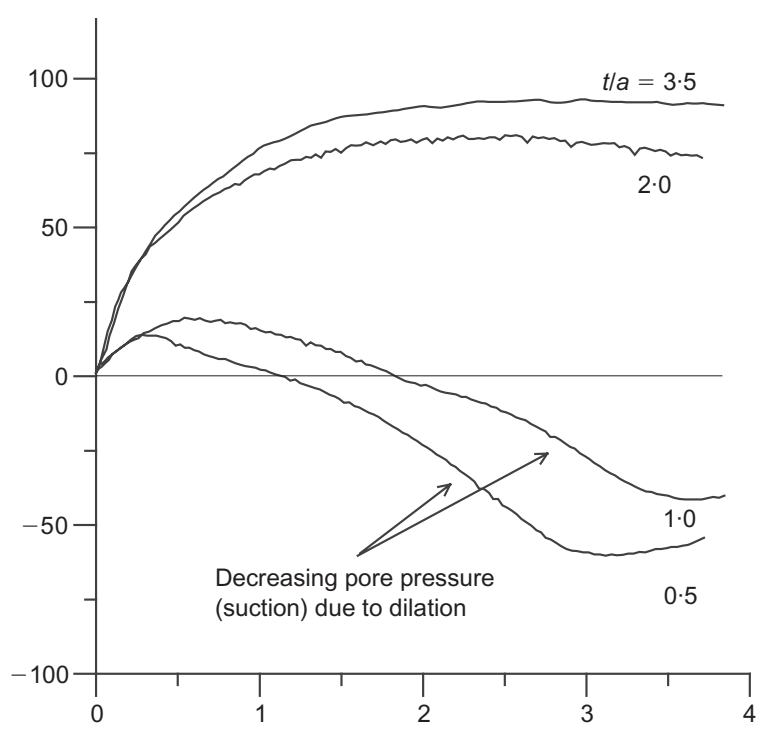

Axial strain: \%

(d)

Fig. 5. Shear behaviour of infilled rock joints inclined at $\beta=60^{\circ}$ in undrained conditions 
solidated undrained $(\mathrm{CU})$ tests under a given pressure were carried out after $300 \mathrm{kPa}$ of back-pressure was applied to ensure saturation. The degree of saturation was evaluated using Skempton's parameter $B$ to be in the vicinity of $0.98-$ 0.99 before shearing.

Shear behaviour was examined at two different effective confining pressures, $\sigma_{3}^{\prime}(200 \mathrm{kPa}$ and $500 \mathrm{kPa})$ for specimens having an infill thickness to asperity height $(t / a)$ ratio of $0 \cdot 5$, $1 \cdot 0,2 \cdot 0$ and $3 \cdot 5$. A shearing rate of $0.05 \mathrm{~mm} / \mathrm{min}$ was considered to be small enough for pore water pressure equalisation within the joint.

\section{RESULTS AND DISCUSSION}

Figures 5(a) and 5(b) show the variation of deviator stress with axial strain during shearing for $t / a$ ratios of $0 \cdot 5,1 \cdot 0$, 2.0 and 3.5 under $200 \mathrm{kPa}$ and $500 \mathrm{kPa}$ effective confining pressure $\left(\sigma_{3}^{\prime}\right)$. These plots illustrate the effect of infill thickness and confining pressure on the shear behaviour of a joint with normally consolidated clay infill. For $t / a \leqslant 1 \cdot 0$, the asperity interference (rock-to-rock contact) is pronounced, especially after an axial strain of $1-2 \%$, and hence the deviator stress increases rapidly. The axial strain required for pronounced asperity interference increases with increasing infill thickness (ie. comparing $t / a=0.5$ and 1.0 ). Also, with decreased confining pressure, the axial strain required for pronounced asperity interference increases considerably. But for $t / a>1 \cdot 0$, the deviator stress gradually increases and attains a constant value, representing the shear behaviour of a normally consolidated clay seam with little or no asperity interference.

The change in excess pore water pressure $(\Delta u)$ with axial strain is plotted in Figs 5(c) and 5(d) for t/a ratios of 0.5 , $1 \cdot 0,2 \cdot 0$ and $3 \cdot 5$, at $\sigma_{3}^{\prime}=200$ and $500 \mathrm{kPa}$. For $t / a \leqslant 1 \cdot 0$ (i.e. clay thickness less than $2 \mathrm{~mm}$ ), the influence of joint roughness (asperities) is significant, where overriding and

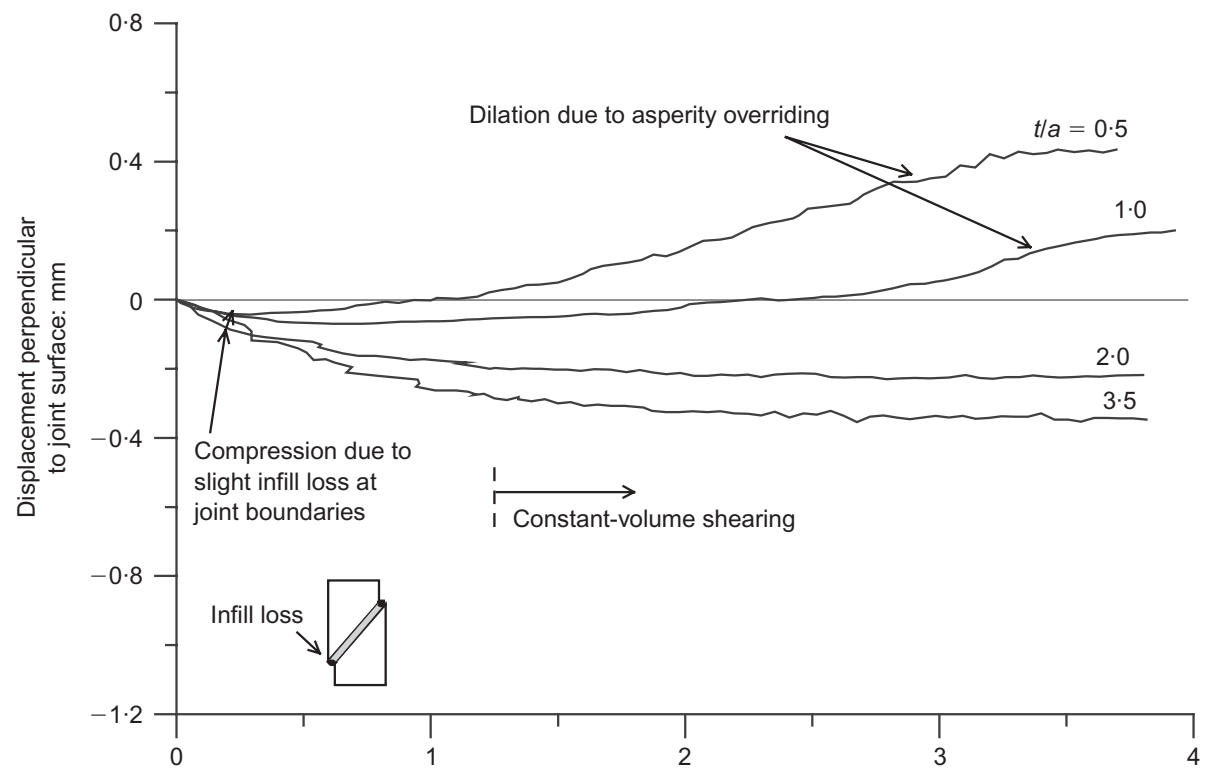

(a)

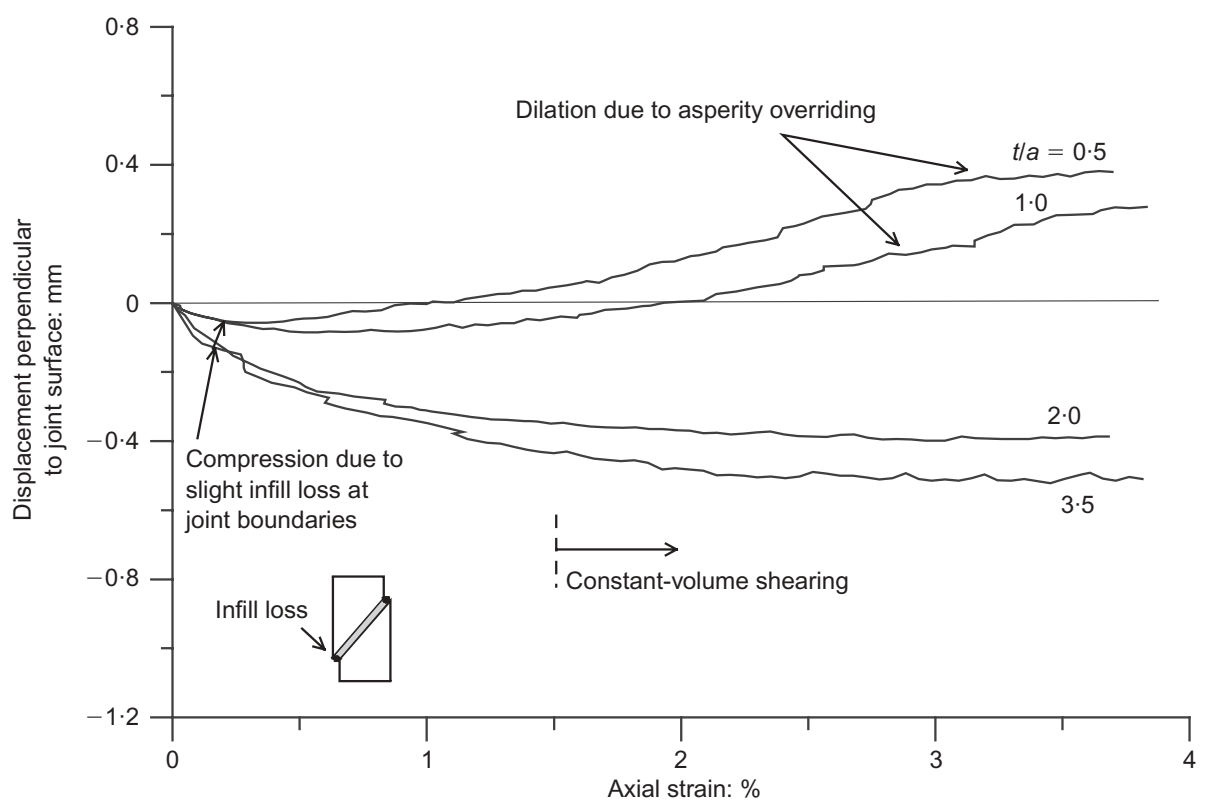

(b)

Fig. 6. Variation of displacement perpendicular to joint surface against axial strain for: (a) $\sigma_{3}^{\prime}=200 \mathrm{kPa}$; (b) $\sigma_{3}^{\prime}=500 \mathrm{kPa}$ 
mating of the joint surfaces cause overall joint dilation and compression respectively (Indraratna et al., 2005). As expected, an increase in $\Delta u$ of the clay infill is observed upon load application, but during joint dilation (Figs 6(a) and 6(b)) $\Delta u$ decreases to the negative range (suction), as shown in Figs 5(c) and 5(d). Direct rock-to-rock contact during shearing may also cause degradation of the asperities and mixing of gouge with the clay infill. The resulting pore pressures and volume changes of the mixed infill are often difficult to interpret. When $\sigma_{3}^{\prime}$ increases from $200 \mathrm{kPa}$ to $500 \mathrm{kPa}$, for $t / a=1 \cdot 0$, the axial strain at which the excess pore water pressure becomes negative decreases from $2.5 \%$ to $1.75 \%$. From Figs 5(c) and 5(d) it is clear that when the infill is relatively thin $(t / a=0 \cdot 5)$, the measured suction is more prominent for axial strain exceeding $1 \%$. This is because of the more pronounced asperity overriding in joints with thin infill layer $(t / a=0.5)$ in comparison with joints having $t / a=1 \cdot 0$. However, when $\sigma_{3}^{\prime}$ increases from $200 \mathrm{kPa}$ to $500 \mathrm{kPa}$, the suction generated in the joints with $t / a=0.5$ is decreased significantly, which can be attributed to the shearing of asperities. In contrast, for $t / a=1 \cdot 0$, where the shearing of asperities is less, the influence of $\sigma_{3}^{\prime}$ on the development of suction is less significant.

In the case of $t / a>1.0$ where the infill thickness is much higher $(4-7 \mathrm{~mm})$, pore water pressure increases continuously to a peak value and then remains almost constant when the deviator stress attains a plateau at axial strains exceeding $1.5 \%$. The associated behaviour is in accordance with undrained shearing of normally consolidated infill at constant volume. However, a small initial compression of the joint (i.e. less than $4 \%$ of the infill thickness) was measured during the initial stages of shearing (Figs 6(a) and 6(b)). This initial compression is caused by the 'squeezing out' of a small amount of infill from the joint boundaries in spite of the latex membrane, and it is not attributed to any drainageinduced volume decrease. Nevertheless, at larger strains, the infilled joint continued to shear with no further compression, obeying the zero volume change behaviour expected of the undrained and saturated infill. When $\sigma_{3}^{\prime}$ was increased from $200 \mathrm{kPa}$ to $500 \mathrm{kPa}$ (Figs 5(c) and 5(d)), a higher excess pore water pressure was measured at elevated deviator stresses.

It is interesting to note that the drop in excess pore water pressure for joints with thin infill layer $(t / a \leqslant 1 \cdot 0)$ is also associated with significant stick-slip behaviour of the corresponding stress-strain curves (Figs 5(a) and 5(b)). This is not evident for joints with a higher infill thickness $(t / a>$ 1.0). Naturally, this observed stick-slip behaviour is attributed to asperity interference - that is, local sliding and over-riding of the asperities - as well as to some asperity degradation during shearing. It has also been reported that a decline in joint pore water pressure could relock the joint walls and further generate stick-slip behaviour (Goodman \& Ohnishi, 1973).

The effective stress path plotted for $q\left[\left(\sigma_{1}^{\prime}-\sigma_{3}^{\prime}\right) / 2\right]$ against $p^{\prime}\left[\left(\sigma_{1}^{\prime}+2 \sigma_{3}^{\prime}\right) / 3\right]$ is shown in Figs $7(\mathrm{a})$ and $7(\mathrm{~b})$, for $\sigma_{3}^{\prime}$ of 200 and $500 \mathrm{kPa}$ respectively. Also, the normally consolidated (NC) stress paths for the same natural clay specimen determined by the authors are shown for comparison. For $t / a \leqslant 1$, the increment of $p^{\prime}$ and $q$ is greater because of increased asperity contact and decreased pore water pressure. When the $t / a$ ratio is increased from 0.5 to $1 \cdot 0$, and from 1.0 to $2 \cdot 0$, the length of the stress paths (extent of variation of $q$ and $p^{\prime}$ ) before failure is shortened considerably. For $t / a>1 \cdot 0$ (i.e. $2 \cdot 0$ and $3 \cdot 5$ ), the observed stress paths are relatively short as the specimens fail at a small value of $q$. Also, it is noted that the stress paths of specimens for $t / a>1.0$ are curved towards the normally consolidated clay specimen, and it is anticipated that the

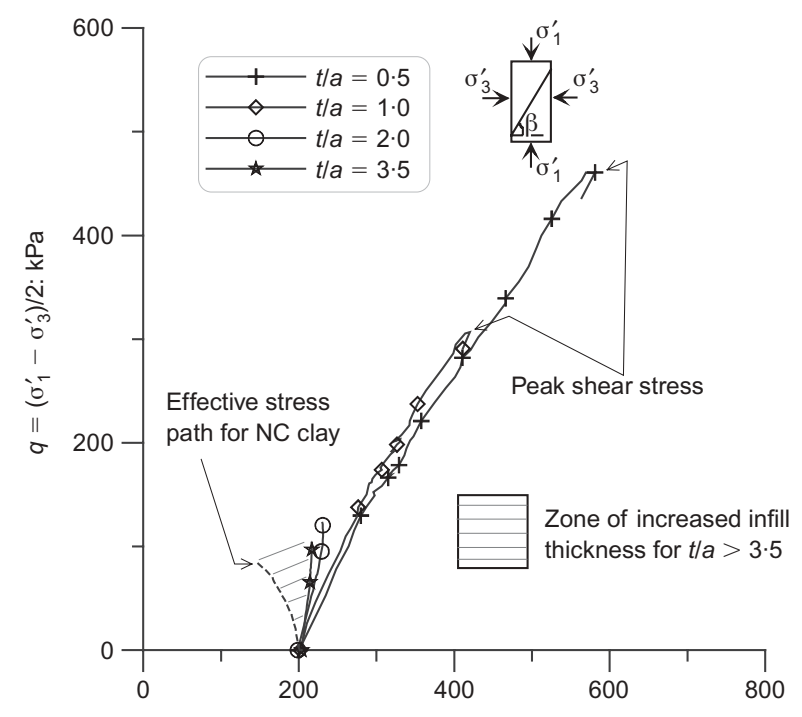

(a)

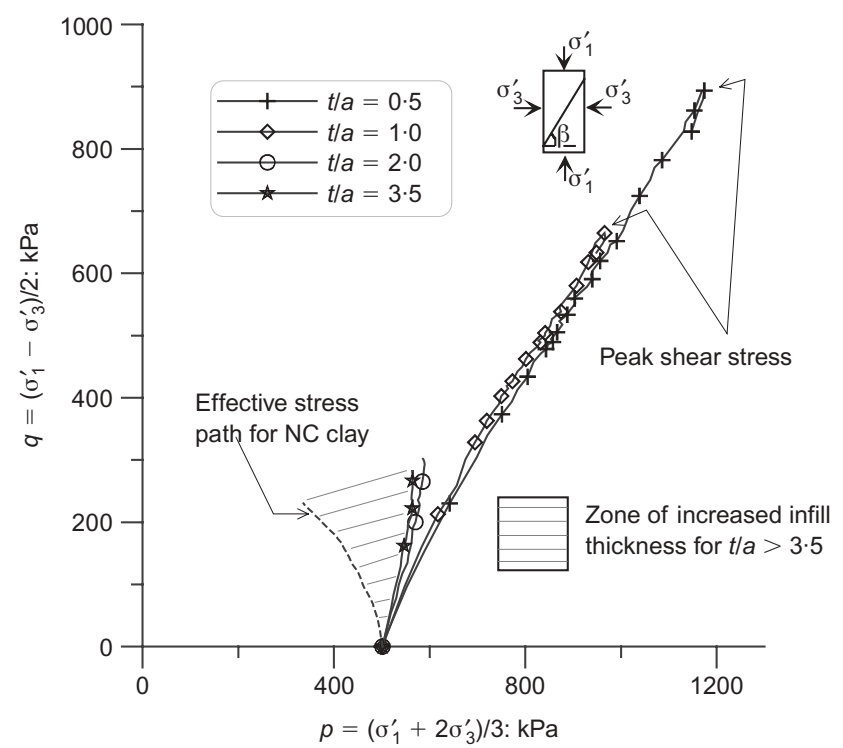

(b)

Fig. 7. Effective stress path plot for infilled rock joints inclined at $\beta=60^{\circ}$, for: (a) $\sigma_{3}^{\prime}=200 \mathrm{kPa}$; (b) $\sigma_{3}^{\prime}=500 \mathrm{kPa}$

greater the $t / a$ ratio, the greater the curvature of the corresponding stress path towards the normally consolidated stress path shown by the dashed lines in Fig. 7.

\section{CONCLUSION}

The purpose of this technical note is to demonstrate a laboratory method for measuring pore water pressure during undrained triaxial shearing of clay-infilled joints. The test data demonstrate that, for a thin clay seam $(t / a \leqslant 1 \cdot 0)$, the stress-strain behaviour is influenced by asperity interference: hence peak shear strength is governed by rock-to-rock contact. Also, for small t/a ratios, asperity overriding causes joint dilation that decreases the build-up of excess pore water pressure in the infill, whereas at high $t / a$ ratios the deviator stress and excess pore water pressure increase continuously and attain a constant value upon shearing. For joints with smaller infill thickness, when confining pressure is increased, there is less suction observed owing to reduced dilation. For higher infill thickness, both excess pore water pressure (positive) and deviator stress increase with the 
increasing confining pressure. This study has also shown that, with a thick clay infill, the infilled joints resemble the shear behaviour of normally consolidated clay, in the absence of asperity interference. It is hoped that these preliminary observations will lead towards a more detailed effective stress analysis of clay-infilled joints.

\section{ACKNOWLEDGEMENTS}

The authors express their gratitude to Dr Jeff Price and Dr Hadi Khabbaz for their useful discussions and comments, and to the geotechnical technicians for their invaluable assistance during the experimental work. Moreover, the untiring efforts of Alan Grant while modifying the triaxial apparatus are appreciated. Finally, the second author would like to thank the Australian Government and the University of Wollongong for their financial support.

\section{REFERENCES}

Archambault, G., Poirier, S., Rouleau, A., Gentier, S. \& Riss, J. (1999). Pore pressure behaviour in undrained triaxial shear tests on joints. Proc. 9th ISRM Int. Cong. on Rock Mechanics, Paris, 741-746.

Archambault, G., Poirier, S., Rouleau, A., Gentier, S. \& Riss, J. (1998). The behaviour of induced pore fluid pressure in undrained triaxial shear test on fracture porous analog rock material specimens. In Mechanics of jointed and faulted rock (ed. H.-P. Rossmanith), pp. 583-589. Rotterdam: Balkema.

de Toledo, P. E. C. \& de Freitas, M. H. (1993). Laboratory testing and parameters controlling the shear strength of filled rock joints. Géotechnique 43, No. 1, 1-19.
Goodman, R. E. \& Ohnishi, Y. (1973). Undrained shear testing of jointed rock. Rock Mechanics 5, No. 3, 129-149.

Indraratna, B. (1990). Development and applications of a synthetic material to simulate soft sedimentary rocks. Géotechnique 40, No. 2, 189-200.

Indraratna, B. \& Haque, A. (1999). Triaxial equipment for measuring the permeability and strength of intact and fractured rock. Géotechnique 49, No. 4, 515-521.

Indraratna, B. \& Ranjith, P. (2001). Laboratory measurement of two-phase flow parameters in rock joints based on high pressure triaxial testing. J. Geotech. Geoenviron. Engng, ASCE 127, No. $6,530-542$.

Indraratna, B., Haque, A. \& Aziz, N. (1999). Shear behaviour of idealized infilled joints under constant normal stiffness. Géotechnique 49, No 3, 331-355.

Indraratna, B., Welideniya, H. S. \& Brown, E. T. (2005). A shear strength model for idealized infilled joints under constant normal stiffness (CNS). Géotechnique 55, No 3, 215-226.

Ladanyi, B. \& Archambault, G. (1977). Shear strength and deformability of filled indented joints. Proceedings of the international symposium on the geotechnics of structurally complex formations, Capri, Vol. 1, pp. 317-326.

Lama, R. D. (1978). Influence of clay fillings on shear behaviour of joints. Proceedings of International Association of Engineering Geology, Madrid, 2, Paper II-43, 27-34.

Lane, K. S. (1970). Engineering problem due to fluid pressure. In Rock mechanics: Theory and practice (ed. W. H Somerton), pp. 501-540. New York: American Institute of Mining, Metrological, and Petroleum Engineering.

Poirier, S., Archambault, G. \& Rouleau, A. (1994). Experimental testing of pore water influences on physico-mechanical properties of a porous rock analog material. Int. Proc. 47th Canadian Geotechnic Conference, Halifax, 418-427. 